\title{
Q fever abortions in ruminants and associated on-farm risk factors in northern Cyprus
}

\author{
Hasan Cantas $^{1 *}$, Adrian Muwonge ${ }^{3}$, Baris Sareyyupoglu$^{2}$, Hakan Yardimci $^{2}$, Eystein Skjerve $^{3}$
}

\section{Background}

Q fever is caused by the obligate intracellular bacterium, Coxiella burnetii $[1,2]$. This disease is regarded as endemic worldwide, with the exception of New Zealand [3-6]. Cattle, sheep and goats are considered to be the primary source of transmission for humans $[7,8]$. Humans are infected mainly by inhalation of contaminated aerosols or by the ingestion of infected milk and/or fresh dairy products. In animals, $Q$ fever is mainly subclinical but has especially been associated with reproductive disorders such as late abortions, stillbirths, weak off springs, metritis and infertility in ruminants [8-11]. Abortions during $\mathrm{Q}$ fever epizootics have been described in goats and sheep, but rarely documented in dairy cows $[7,12]$.

Domestic pets, such as cats, dogs and wild-domestic birds such as rock doves (Columba livia) and geese (Anser anser) are known to be an additional source of infection [8,12-14]. Previous studies have reported occurrences of C. burnetii in migratory wild birds, rodents and ticks in southern Cyprus [15-17]. More than 40 species of ticks are naturally infected with C. burnetii. However, besides the aerosol route, the significance of ticks in transmitting the disease in ruminants and humans has previously been documented $[8,9]$. On the other hand, recent studies showed that ticks seem to play a major role in the circulation of C. burnetii in cycles of nature especially in wild life cycles. Ticks are also believed to probably play another crucial role in the transmission of the agent from infected wild vertebrates to domestic animals $[5,18,19]$.

In humans, $\mathrm{Q}$ fever is mostly asymptomatic, the acute disease form is mainly limited flu-like illness, pneumonia or hepatitis while the chronic disease manifests with chronic fatigue syndrome or endocarditis $[4,5,20]$. On the reproductive health point of view, $C$. burnetii infections are known to cause abortions, stillbirth and pre-

\footnotetext{
* Correspondence: Hasan.Cantas@nvh.no

'Department of Food Safety and Infection Biology, Norwegian School of Veterinary Science, P.O. Box 8146 Dep., 0033 Oslo, Norway

Full list of author information is available at the end of the article
}

mature deliveries in pregnant women. In the past, a series of Q fever outbreaks in both human and animal populations resulting in abortions on the island of Cyprus have been reported $[10,21]$. Studies done on the islands as far back as the 1970's showed that Q fever has been an ongoing public health problem. Recently, the prevalence of IgG antibodies against C. burnetii phase II antigens was estimated to be at $52.7 \%$ for humans, $48.2 \%$ for goats, $18.9 \%$ for sheep, and $24 \%$ for cows. In this context, control of C. burnetii infection in ruminants is a vital component of public health [19]. There is no known record of humans contracting Q fever in northern Cyprus, which might be linked with lack of routine screenings and/or insufficient diagnostic units for C. burnetii [Northern Cyprus Ministry of Health, 2008].

The diagnostic enigma is that C. burnetii is difficult to culture, and detection in Cyprus was first done by complement fixation of antibodies [22,23]. Lately detection and diagnosis of $C$. burnetii, has been more effectively done by PCR based techniques, targeting the isocitrate dehydrogenase, superoxide dismutase gene and a transposon-like repetitive region [15,24-28]. The current technological advancement in these techniques has made them the most useful diagnostic tools for detection of C. burnetii in bovine aborted foetuses and ovine genital swabs [29-31].

Since the division of Cyprus in 1974, there has not been any research work on this disease in the northern region. Therefore, the aim of this study was to determine the occurrence of $\mathrm{Q}$ fever abortion using a PCR based method on DNA isolated from aborted foetal abomasal contents and placental tissues from ruminants in northern Cyprus. In addition, to determine the on-farm risk factors associated with the disease.

\section{Methods}

Study area

Northern Cyprus covers about $37 \%$ of the third largest island in the Eastern Mediterranean, located south of 
Turkey and west of Syria and Lebanon and is divided into three main regions; Northbound Region (Kyrenia and North of Nicosia), Border Region (Morphou, South of Nicosia, Famagusta and Vadili) and Karpas Region (Gecitkale, Iskele). It has a population of 265.100 people [Governmental Planning Office-Northern Cyprus 2006]. The economy is dominated by the service sector, but the animal husbandry industry is growing steadily. The region has a ruminant population of approximately 50.000 bovine of which 18.000 are milking cows, 185.000 are sheep and 45.000 are goats [Northern Cyprus Veterinary Service 2008]. Climatically, summers are dry and hot while winters are mild. The average annual temperature and rainfall is $19^{\circ} \mathrm{C}$ and $345 \mathrm{~mm}$ respectively. The dairy based regions are located at sea level and cattle raring is more intensive than semiextensive for small ruminant farms. Generally milking cow farms are urged to report any cases of abortions in order to be compensated for the economical loses. However, this policy does not apply to small ruminant farms [Northern Cyprus Veterinary Service 2008]

\section{Study design and sampling strategy}

This study was based on a cross-sectional convenient sampling strategy. The government veterinary services received a total of 622 reports of third trimester cow abortion cases from the entire northern region in the period between October 2008 and March 2009. Owing to long distances between the farms, lack of coordination between farmers and veterinary services, financial logistical problems, only 51 different milking cow casefarms were conveniently visited and abortion materials were sampled from 51 different cows. As small ruminant farmers were not urged to declare abortions, only eight different small ruminant abortions/farms (6 sheep and 2 goats) could be included into this study. Abomasal content and a piece of cotyledon were collected from each abortion case, therefore a total 59 abortion case materials were collected in duplicates (abomasal content and cotyledon). A questionnaire was also administered to each visited farm. Information regarding; geographical location of farm, type of sampled animal, and type of animal feed, cleaning frequency of barn floor, presence of carnivores, pigeons on the farm and the presence of ticks on aborted animal was gathered. In addition, weather information was also collected from the meteorological centre in northern Cyprus during the study period.

\section{Sample collection and laboratory analysis}

Sterile latex gloves and face masks (that adequately cover the mouth and nose) were used during the sample collection procedures. A piece of cotyledon sample $(20 \mathrm{~g})$ was carefully cut from the placenta and placed in a sterile labeled collection container, thereafter the fetus was dissected to expose the abomasum from which abomasal contents $(5-10 \mathrm{ml})$ were collected and placed in a separate sterile tubes. Gloves were changed between each collection to avoid cross contamination. The samples were then transported in a cold box to the laboratory in Ankara.

DNA was extracted from foetal abomasal contents and placental cotyledon using the DNeasy Blood \& Tissue $\mathrm{Kit}^{\circledR}$ (Qiagen S.A., France). The positive ready to use control DNA of C. burnetii Nine Mile phase II strain was provided by Dr. Amanda Loftis Rickettsial Zoonoses Branch, Centers for Disease Control and Prevention, Atlanta, USA.

Two different PCR reactions (CB-PCR and TransPCR) were run as described below:

Initially, a 257 base pair (bp) fragment was amplified by CB-PCR to detect superoxide dismutase gene with CB-1 and CB-2 primers [32]. Thereafter, a 687 bp fragment was amplified by Trans-PCR to detect IS1111A transposase gene with Trans- 1 and Trans-2 primers [28]. These two PCR reactions were performed in $25 \mu \mathrm{l}$ reaction mixture containing $2.5 \mu \mathrm{l}$ template DNA, $2.5 \mu \mathrm{l}$ 10xPCR Buffer, $3 \mu \mathrm{l} 25 \mathrm{mM} \mathrm{MgCl}, 0.5 \mu \mathrm{l} 10 \mathrm{mM}$ dNTP mix, 5 pMol each of forward and reverse primers, $1 \mathrm{U}$ of Taq DNA polymerase (Fermentas, Vilnius, Lithuania) and $15.4 \mu \mathrm{l}$ sterile nuclease-free PCR grade water. In order to avoid cross contamination the PCR mixture was prepared in laminar flow cabinet equipped with a UV lamp, in a separate room. During the process fresh gloves were used and pipette tips with aerosol filters were preferred. DNA amplifications were performed in a T1 Thermocycler (Biometra, Germany). Positive and negative control (ultra pure water) samples were included in all amplifications. PCR conditions and amplification cycles were identical with previously described original protocols $[26,28]$. PCR assay specificity was tested with the amplification protocols described above using DNA extracted from all field and reference $C$. burnetii Nine Mile phase II strain as a template that has a known concentration $(65 \mathrm{ng} / \mathrm{ml})$ of ready to use DNA. The resultant PCR products were analyzed on $1.5 \%$ agarose gel. After electrophoresis at $100 \mathrm{~V}$ for $60 \mathrm{~min}$, gels were stained with ethidium bromide and visualized by a Bio Imaging System (Syngene, Cambridge, UK).

\section{Data analysis}

A positive animal was defined as one that was positive on both tests on DNA isolated from abomasal content, therefore this served as the gold standard for this study. The on farm based variables like source of feed for animals, frequency of litter cleaning, presence of ticks on aborted animals, pigeons, rodents and carnivores on the 
farm were coded and together with the corresponding PCR based test results from each farm were entered in a Microsoft Excel ${ }^{\circledR}$ spreadsheet. After validation the data was then transferred to Stata (stata/SE 10 for Windows, StataCorp, College Station,TX) for statistical analysis. A survey-data-analysis procedure was used for estimating the occurrence of $\mathrm{Q}$ fever. The univariable association of Q fever (Odds ratio with 95\% CI) with individual exposure variables, considering individual animal as primary sampling unit was determined. A $p \geq 0.25$ was used as a cut off value for exposure factors that were included in the univariable analysis, a Multivariable logistic regression model analysis was then built with forward selection procedure to determine the risk factors. Model validity and reliability was assessed using the Hosmer-Lemeshow goodness of-fit test and receiver operating curve (ROC) respectively. In addition the degree of agreement between the two PCR diagnostic methods on each sample was analyzed using the Kappa agreement measure using SISA http://www.quantitativeskills.com/sisa/statistics/diagnos.htm online based software.

\section{Results}

Of the 59 sampled ruminants, twenty two (37\%) were positive for both PCR based tests on foetal abomasal content used in this study (Table 1). 35\% (18/51) of bovine, $33 \%(2 / 6)$ of sheep and $50 \%(1 / 2)$ of goat abortion cases were positive for $C$. burnetii with the Trans and CB PCRs test foetal abomasal content. Nineteen (\% 32.2) of uterine cotyledon DNA were positive for both PCR test (Table 2). The diagnostic agreement of the tests is compared in Table 1 and Table 2. Trans-PCR and CB-PCR assay had a kappa diagnostic agreement of $64 \%$ and $68 \%$ on foetal abomasal content and uterine cotyledon respectively.

Table 3 shows geographical distribution in the occurrence of C. burnetii abortion among ruminants, 35\%, 53\% and $42 \%$ of the reported sample abortion cases in the Northbound Region, Border Region and Karpas Region respectively were caused by $C$. burnetii. The univariable analysis shows that farms which used commercially

Table 1 Diagnostic agreement between CB-PCR and Trans-PCR assay on DNA isolated from abomasal content

\begin{tabular}{|c|c|c|c|c|}
\hline \multicolumn{5}{|c|}{ Cows $_{(51)}$ - Sheep $(6)$ - Goat ${ }_{(2)}$ Abortions } \\
\hline & \multicolumn{4}{|c|}{ Trans-PCR } \\
\hline & & Positive & Negative & Total \\
\hline & Positive & 22 & 5 & 27 \\
\hline \multirow[t]{3}{*}{ CB-PCR } & Negative & 7 & 35 & 32 \\
\hline & Total & 29 & 40 & 59 \\
\hline & & \multicolumn{3}{|c|}{$\begin{array}{c}\text { Kappa agreement between CB and Trans PCR 64\% } \\
\text { (34-94) SE 12\% }\end{array}$} \\
\hline
\end{tabular}

Table 2 Diagnostic agreement between CB-PCR and Trans-PCR assay on DNA isolated from placental cotyledons

\begin{tabular}{|c|c|c|c|c|}
\hline \multicolumn{5}{|c|}{ Cows $_{(51)}$ - Sheep $(6)-$ Goat $_{(2)}$ Abortions } \\
\hline \multicolumn{5}{|c|}{ Trans-PCR } \\
\hline & & Positive & Negative & Total \\
\hline & Positive & 19 & 6 & 25 \\
\hline \multirow[t]{3}{*}{ CB-PCR } & Negative & 4 & 40 & 44 \\
\hline & Total & 23 & 46 & 59 \\
\hline & & \multicolumn{3}{|c|}{$\begin{array}{c}\text { Kappa agreement between CB and Trans PCR 68\% } \\
\text { (38-98) SE 12\% }\end{array}$} \\
\hline
\end{tabular}

produced feed and cleaned litter more than 10 times in a year were less likely to have abortions due to C. burnetii compared to those using farm-made feed and clean litter $<5$ times in a year (Table 3 ). The logistic regression model identified ticks $(\mathrm{OR}=4 ; \mathrm{P}=0.05)$, poor hygiene $(\mathrm{OR}=0.3 ; \mathrm{P}=0.05$ and $\mathrm{OR}=0.09 ; \mathrm{P}=0.05)$ and presence of carnivores $(\mathrm{OR}=3 ; \mathrm{P}=0.01)$ as the on-farm risk factors associated with occurrence of $C$. burnetii abortions (Table 4). The logistic regression model fits the data (HL $\chi 2=3.01 ; \mathrm{P}=0.69$ ) and the evaluation of reliability showed that it was reliable $(\mathrm{ROC}=0.84$ and 0.79 ).

The veterinary service data base had a total of 1415 abortions among ruminants between October 2008 and September 2009. However, 662 of these were reported during the time of study. The lowest registered number of abortion cases in the general data base was in November while the lowest occurrence of $C$. burnetii abortions was in December. However, this occurrence gradually increased from January to another peak in February and then decreased towards March. The C. burnetii abortions and presence of ticks on abortion cow cases seem to follow the gradual fall in temperature as the season transition from autumn to winter (Figure 1).

\section{Discussion}

To the best of our knowledge, this is the only documented epidemiological study on $\mathrm{Q}$ fever in ruminants in northern Cyprus since 1974. From a total of 59 randomly sampled abortion cases in ruminants, 22 (37\%) were found to be caused by C. burnetii. This is higher than the prevalence documented in Italian domestic ruminant abortions (22.35\%) [33]. Border Region (53\%, 11/26) had the highest occurrence of C. burnetii related abortions (Table 3). This region is mostly a rural area and based on the questionnaire, poor hygiene practices may explain the relatively high occurrence of $C$. burnetii abortions. Furthermore, in a previous larger study, Psaroulaki et al. 2006 showed that the border region had the highest cumulative sero-prevalance rates of $C$. burnetii specific antibodies in small ruminants, in southern Cyprus. Although animal flocks have not been in close contact among the border line since 1974, in 
Table 3 Univariate association between recorded exposure factors and prevalence of $Q$ fever abortions in ruminants

\begin{tabular}{|c|c|c|c|c|}
\hline Variable & Label & No of examined animals & PCR positive for $C$. burnetii & $\mathrm{p}$-value \\
\hline \multirow[t]{3}{*}{ Regions } & Northbound Region & 13 & 7 & - \\
\hline & Border Region & 26 & 11 & 0.50 \\
\hline & Karpas Region & 20 & 7 & 0.30 \\
\hline \multirow[t]{2}{*}{ Animals } & Cows & 51 & 21 & - \\
\hline & Sheep and Goat & 8 & 4 & 0.64 \\
\hline \multirow[t]{3}{*}{ Feed Type } & Farm-made Feed & 28 & 19 & - \\
\hline & Commercial Feed & 23 & 3 & 0.00 \\
\hline & Both of The Above & 8 & 3 & 0.13 \\
\hline \multirow[t]{3}{*}{ Frequency of Litter Cleaning } & $<5$ Times/Year & 23 & 19 & - \\
\hline & $5<\times<10$ Times/Year & 20 & 5 & 0.001 \\
\hline & $>10$ Times/Years & 16 & 1 & 0.001 \\
\hline \multirow[t]{2}{*}{ Presence of Rodents in Animal Housing } & Absent & 33 & 9 & - \\
\hline & Present & 26 & 16 & 0.01 \\
\hline \multirow[t]{2}{*}{ Ticks on aborted Animals } & Absent & 29 & 2 & - \\
\hline & Present & 30 & 23 & 0.001 \\
\hline \multirow[t]{2}{*}{ Houseflies on Farm } & Absent & 23 & 4 & - \\
\hline & Present & 36 & 21 & 0.003 \\
\hline \multirow[t]{2}{*}{ Pigeons on Farm } & Absent & 24 & 3 & - \\
\hline & Present & 35 & 22 & 0.001 \\
\hline \multirow[t]{2}{*}{ Presence of Carnivores at Farm } & Absent & 30 & 4 & 0.001 \\
\hline & Present & 29 & 21 & 0.001 \\
\hline
\end{tabular}

epidemiological frame-work $[4,6]$ uncontrolled C. burnetii in northern part (particularly in Border region) may play a key role in the circulation of the problem between two areas.

C. burnetii is a fastidious intracellular bacterium whose isolation requires several days to weeks involving a difficult and yet hazardous procedure. This is in addition to the heterogeneity in growth conditions required by the different strains of C. burnetii [34]. Therefore, the international office of epizootics (O.I.E) recommends PCR as one of the most effective methods for C. burnetii diagnosis. Trans-PCR and CB-PCR assay had a diagnostic agreement measure of $64 \%$ and $68 \%$ on foetal abomasal contents and uterine cotyledon respectively (Table 1 and Table 2). This disparity could be due to the fact that placental tissues are prone to contamination from faecal material during abortion, which is known to contain inhibitors to Taq polymerase [35]. These inhibitors can therefore interfere with the PCR procedure and thus affect the results. Anti-inhibitors of Qiamp Tissue DNA purification procedure were used but it is possible that did not completely eliminate PCR inhibitors from placental cotyledons. This finding is in agreement with the study by [29]. Therefore animals were deemed positive if they were found positive for both tests on DNA from foetal abomasal content based on this fact. This study therefore found that a combination of Trans PCR and CB-PCR assay on foetal abomasal content gave a better diagnostic edge.

This study also found tick presence on aborted animals $(\mathrm{OR}=4 ; \mathrm{P}=0.05)$ as the most plausible on farm management risk factor with regards to $Q$ fever

Table 4 Multivariable logistic regression model for risk factors associated with $\mathbf{Q}$ fever abortion in ruminants

\begin{tabular}{ccccc}
\hline Variables & Level & Odds ratio & P-value & 95\% Cl \\
\hline Ticks on aborted animals & Absent & 1.00 & - & - \\
& Present & 4.54 & 0.05 & $0.96-21.32$ \\
Frequency of litter cleaning & $<5$ times/year & 1.00 & - & - \\
& $5<\times 10$ times/year & 0.30 & 0.05 & $0.04-1.00$ \\
Carnivores on Farm & $>10$ times/year & 0.09 & 0.05 & - \\
& Absent & 1.00 & - & 0.023 \\
& Present & 3.33 & 0.01 & $0.762-1.02$ \\
\hline
\end{tabular}


occurrence in northern Cyprus (Table 4). It has been documented that in nature C. burnetii is found primarily in a cycle where ticks play a significant role in transmitting the pathogen among wild vertebrates, such as rodents, lagomorphs, and wild birds $[8,18,36]$. This therefore concurs with studies done before showing the key role ticks play as transmitting agents of C. burnetii between wild life and livestock $[6,8]$. On the other hand, carnivore (dogs and cats) presence on the farm also presented an additional risk $(\mathrm{OR}=3 ; \mathrm{p}=0.01)$ however, like the rodents these seem to fit in tick transmission cycle as elaborated in studies done by $[9,18]$.

Good hygiene practices are an important way of reducing the risk of spread of infectious diseases, and the findings of this study agree with this notion. The higher the frequency of litter cleaning $(5<x<10$ and $x>10$ times/year) on farm the more protective $(\mathrm{OR}=0.3$; $\mathrm{P}=$ 0.05 and $\mathrm{OR}=0.09 ; \mathrm{P}=0.05)$ it was against the risk of $\mathrm{Q}$ fever (Table 4). C. burnetii is a pathogen known to be resistant to disinfectants and environmental factors, and Brouqui et al. 2007 reported that C. burnetii could survive for years in animal faeces for 8-9 months in sand and 19 months in dried tick faeces. Studies done in rural areas have all indicated that poor hygiene could be an exacerbating factor in the spread of C. burnetii $[37,38]$.

This study also found a seasonal variation in the occurrence of C. burnetii abortions in northern Cyprus (Figure 1). The highest occurrence was experienced in October which gradually declined to the lowest in
December. This trend follows the steady fall of temperatures that characterizing the transition from autumn to winter. This change of season could have a direct effect on tick prevalence which then indirectly affects the occurrence of the disease in this region. Unfortunately this study did not examine the tick species on abortion ruminant cases, but previous studies showed that more than 40 species are naturally infected and play role in transmission of the agent $[8,9]$. Therefore regardless of the tick species, presence of ticks on farm is a risk given the wide tick species range that carry C. burnetii. The seasonal variation of C. burnetii has previously been documented in cattle in Japan [39], however, this study documented in sero-prevalance rates. On the other hand in humans, seasonality has been seen to occur in spring following the outdoor lambing of sheep in southern Germany [40]. Unfortunately, no data are yet available on the occurrence of human Q fever in northern Cyprus. The findings of our study suggest that more investigations are necessary on this largely underestimated public health issue in northern Cyprus.

Human disease contracted from livestock is already a public health problem in southern Cyprus [41]. The identified risk factors in this study can be used to avert a potentially catastrophic public health problems in northern Cyprus in the following ways; i) on the farm level, a stringent tick control strategy is very important in breaking the spreading cycle to cattle, carnivores, rodents and pigeons. In addition rodent free housing is paramount in removing the extra circulating agents.

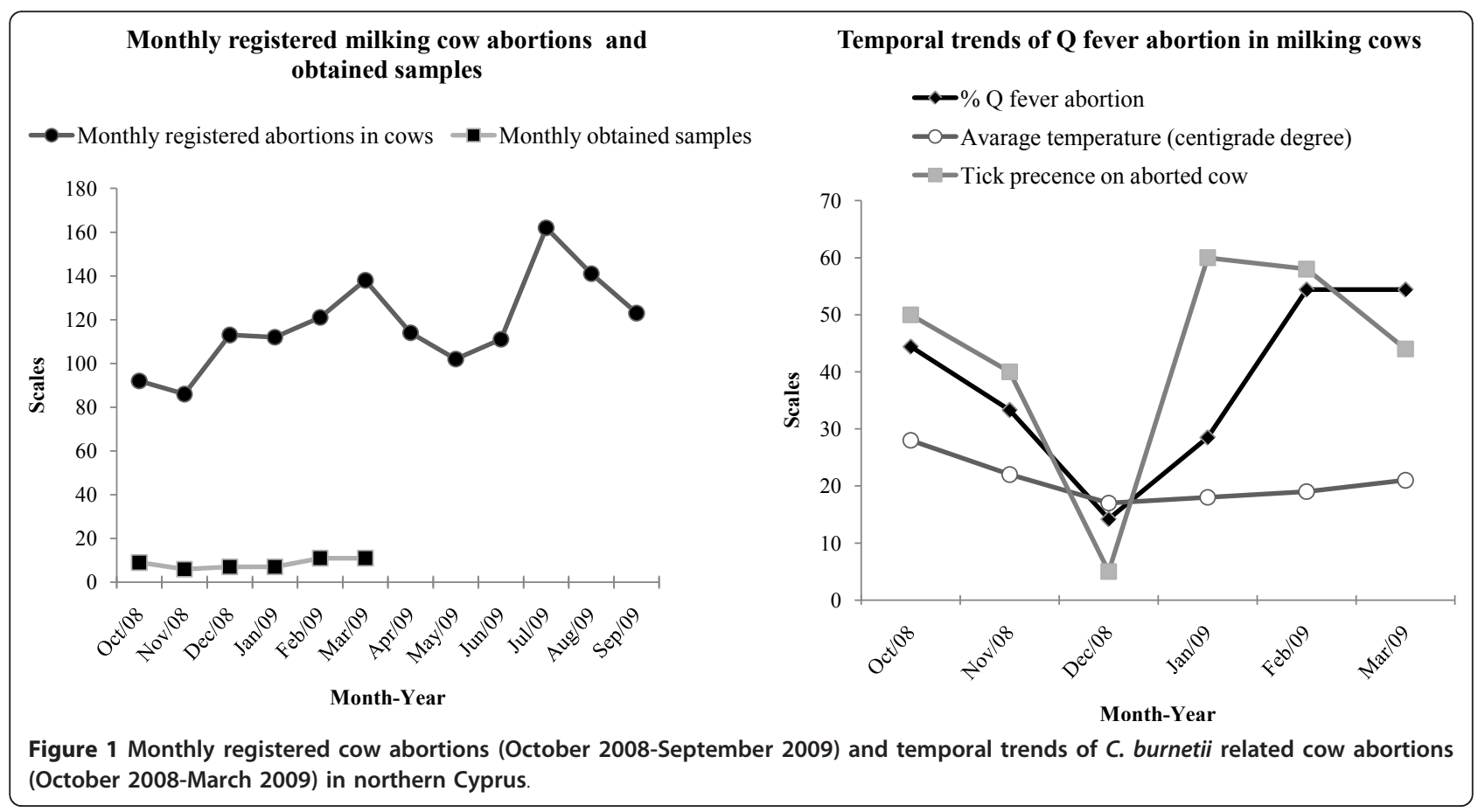


Hygiene on farm should be a routine management practice, ii) at National level besides milking cow abortions, small ruminant farms also should be urged to declare abortion cases, it is important to put in place a vigorous surveillance system to keep track of outbreaks and occurrences given the endemic nature of the infection. This ought to be in addition to a strategic vaccination scheme, iii) on a regional level, given the differences in disease occurrence between northern and southern Cyprus. There should be a strict control of animal movement between the two regions and a joint concerted effort with regard to disease control and research on regional based vaccine development.

\section{Conclusions}

In conclusion, this study found a significantly high occurrence of C. burnetii abortions in northern Cyprus. Ticks on aborted animals and poor hygiene were identified as the most important on-farm risk factors associated with C. burnetii abortions. In additional Trans-PCR and CB-PCR assay on foetal abomasal content was a better diagnostic combination.

\section{Acknowledgements}

This research found by The Scientific and Technological Research Council of Turkey (TUBITAK) and has been performed at Department of Microbiology, Molecular Microbiology Laboratories, Faculty of Veterinary Medicine, Ankara University. Also we are thankful to Prof. Henning Sorum from Norwegian School of Veterinary Medicine who contributed his wealth of experience to the study design. We extend our thanks to Errol Ibrahim, BSc for his help in reviewing article. Finally we greatly acknowledge the efforts of the Veterinary Services of northern Cyprus during the sample collection.

\section{Author details}

'Department of Food Safety and Infection Biology, Norwegian School of Veterinary Science, P.O. Box 8146 Dep., 0033 Oslo, Norway. ${ }^{2}$ Department of Microbiology, Faculty of Veterinary Medicine, Ankara University, Diskapi, 06110 Ankara, Turkey. ${ }^{3}$ Centre for Epidemiology and Biostatistics, Norwegian School of Veterinary Science, P.O. Box 8146 Dep., 0033 Oslo, Norway.

\section{Authors' contributions}

$\mathrm{HC}$ contributed to the establishment of the collaborations, design, conception, data collection, performed the all laboratory work, data analysis, drafting and writing of the manuscript. AM contributed data analysis, drafting and writing of the manuscript. BS contributed to laboratory analysis, design and supervision of the manuscript. HY contributed to the acquisition of funds, drafting of the manuscript. ES contribute to the supervision, drafting and writing of the manuscript. All authors contributed to the final version of the manuscript, read and approved it.

Received: 11 October 2010 Accepted: 17 March 2011

Published: 17 March 2011

\section{References}

1. Africau-Bouvery $\mathrm{N}$, Rodolakis $\mathrm{A}$ : Is $\mathrm{Q}$ fever an emerging or re-emerging zoonosis? Vet Re 2005, 36:327-349.

2. Kovácová E, Kazár J: Q fever-still a query and underestimated infectious disease. Acta Virol 2002, 4:193-210.

3. Hilbink F, Penrose M, Kovacova E, Kazar J: Q fever is absent from New Zealand. Int J Epidemiol 1993, 22:945-9.

4. Marrie TJ: Epidemiology of Q fever. In Q Fever. Volume 1. The Disease Edited by: Marrie TJ. Boca Raton: USA CRC Press; 1990:49-70.

5. Maurin M, Raoult D: Q fever. Clin Microbiol Rev 1999, 12:518-553.
6. Norlander L: Q fever epidemiology and pathogenesis. Microbes Infect 2000, 2:417-424

7. Brouqui P, Marrie T, Raoult D: Coxiella. In Manual of Clinical Microbiology 9 edition. Edited by: Murray P, Baron EJ, Jorgensen JH, Landry ML, Pfaller MA. Washington, DC: ASM Press; 2007:1062-1069.

8. Lang $\mathrm{GH}$ : Coxiellosis (Q fever) in animals. In Q Fever. Volume 1. The Disease Edited by: Marrie TJ. Boca Raton, USA: CRC Press; 1990:23-48.

9. Aitken ID, Bogel K, Cracea E, Edlinger E, Houwers D, Krauss H, Rady M, Rehacek J, Schiefer HG, Schmeer N: Q fever in Europe: Current Aspects in Aetiology, Epidemiology, Human Infection, Diagnosis and Therapy. Infection 1987, 15:323-327.

10. Spicer AJ, Crowther RW, Vella EE, Bengtsson E, Miles R, Pitzolis G: Q fever and animal abortion in Cyprus. Trans R. Soc Trop Med Hyg 1977, 71:16-20.

11. To H, Htwe KK, Kako N, Kim HJ, Yamaguchi TH, Fukushi S, Hirai K: Prevalence of Coxiella burnetii infection in dairy cattle with reproductive disorders. J Vet Med Sci 1998, 60:859-861.

12. Babudieri B, Moscovici C: Experimental and natural infection of birds by Coxiella burnetii. Nature (London) 1952, 169:195-196.

13. Ho T, Ritsuko S, Kazutoshi S, Chiaki K, Satomi A, Tomoaki S, Kazuaki T, Chiharu M, Ikuo T, Tsutomu M, Tsuyoshi Y, Hideto F, Katsuya H: Coxiellosis in domestic and wild birds from Japan. J Wildlife Dis 1998, 34:310-318.

14. Kotatsky T: Household outbreak of Q-fever pneumonia related to a parturient cat. Lancet 1984, 2:1447-1449.

15. Ioannou I, Chochlakis D, Kasinis N, Anayiotos P, Lyssandrou A, Papadopoulos B, Tselentis Y, Psaroulaki A: Carriage of Rickettsia spp., Coxiella burnetii and Anaplasma spp. by endemic and migratory wild birds and their ectoparasites in Cyprus. Clin Microbiol Infect 2009, 2:158-160

16. Psaroulaki A, Antoniou M, Toumazos P, Mazeris A, loannou I, Chochlakis D, Christophi N, Loukaides P, Patsias A, Moschandrea I, Tselentis Y: Rats as indicators of the presence and dispersal of six zoonotic microbial agents in Cyprus, an island ecosystem: a seroepidemiological study. Trans $R$ Soc Trop Med Hyg 2010, 104:733-739.

17. Spyridaki I, Psaroulaki A, Loukaides F, Antoniou M, Hadjichristodolou C, Tselentis Y: Isolation of Coxiella burnetii by a centrifugation shell-vial assay from ticks collected in cyprus: detection by nested polymerase chain reaction (PCR) and by PCR-restriction fragment length polymorphism analyses. Am J Trop Med Hyg 2002, 66:86-90.

18. Marrie TJ, Schlech WF, Williams JC, Yates L: Q fever pneumonia associated with exposure to wild rabbits. Lancet 1986, 327:427-429.

19. Psaroulaki A, Hadjichristodoulou C, Loukaides F, Soteriades E, Konstantinidis A, Papastergiou P, loannidou MC, Tselentis Y: Epidemiological study of $\mathrm{Q}$ fever in humans, ruminant animals, and ticks in Cyprus using a geographical information system. Eur J Clin Microbiol Infect Dis 2006, 25:576-586.

20. Marrie TJ: Q fever pneumonia. Curr Opin Infect Dis 2004, 17:137-42.

21. Spicer AJ: Military significance of $Q$ fever: a review. J Royal Society of Med 1978, 71:762-767.

22. Kaplan MM, Bertagna P: The geographical distribution of $\mathrm{Q}$ fever. Bull World Health Org 1955, 13:829-860.

23. Polydorou K: Q fever in Cyprus: a short review. Br Vet J 1981, 137:470-477.

24. Hoover TA, Vodkin MH, Williams JC: A Coxiella burnetii repeated DNA element resembling a bacterial insertion sequence. J Bacterio/ 1992, 174:5540-5548.

25. Nguyen SV, Hirai K: Differentiation of Coxiella burnetii isolates by sequence determination and PCR-restriction fragment length polymorphism analysis of isocitrate dehydrogenase gene. FEMS Microbiol Lett 1999, 180:249-254

26. Stein A, Raoult D: Detection of Coxiella burnetii by DNA amplification using Polymerase Chain Reaction. J Clinical Microbiol 1992, 30:2462-2466.

27. Willems H, Cornelie J, Georg B: Physical and genetic map of the obligate intracellular bacterium, Coxiella burnetii. J Bacteriol 1998, 180:3816-3822.

28. Willems $H$, Thiele D, Frolich-Ritter $\mathrm{R}$, Krauss $\mathrm{H}$ : Detection of Coxiella burneti in cow's milk using the polymerase chain reaction (PCR). Zentralb/ Veterinarmed B 1994, 41:580-587.

29. Berri M, Laroucau K, Rodolakis A: The detection of Coxiella burnetii from ovine genital swabs, milk and fecal samples by the use of a single touchdown polymerase chain reaction. Vet Microbiol 2000, 15(3-4):285-93.

30. Berri M, Souriau A, Crosby M, Rodolakis A: Shedding of Coxiella burnetii in ewes in two pregnancies following an episode of Coxiella abortion in a sheep flock. Vet. Microbiol 2002, 85:55-60. 
31. Lorenz H, Jager C, Willems H, Baljer G: PCR Detection of Coxiella burnetii from Different Clinical Specimens, Especially Bovine Milk, on the Basis of DNA Preparation with a Silica Matrix. Appl. Environ. Microbiol 1998, 64:4234-4237.

32. Heinzen RA, Frazier ME, Mallavia LP: Nucleotide sequence of Coxiella burnetii superoxide dismutase. Nucleic Acids Res 1990, 18(21):6437.

33. Parisi A, Fraccalvieri R, Cafiero M, Miccolupo A, Padalino I, Montagna C, Capuano F, Sottili R: Diagnosis of Coxiella burnetii-related abortion in Italian domestic ruminants using single-tube nested PCR. Vet Microbiol 2006, 118:101-106

34. Stein A, Raoult D: Phenotypic and genotypic heterogeneity of 8 new human Coxiella burnetii isolates. Acta Virol (Prague) 1992, 36:7-12.

35. Wild J, Eiden J, Yolken R: Removal of inhibitory substances from human fecal specimens for detection of group A rotavirus by reverse transcriptase and polymerase chain reactions. J Clin Microbiol 1990, 28:1300-1307.

36. Stein A, Raoult D: Pigeon pneumonia in provence: a bird-borne $Q$ fever outbreak. Clin Infect Dis 1999, 29:617-620.

37. Luoto $L$ : Report on the nationwide occurrence of $Q$ fever infections in cattle. Public Health Rep 1960, 75:135-140.

38. Lyytikäinen $\mathrm{O}$, Ziese $T$, Schwartländer $B$, Matzdorff $P$, Kuhnhen $C$, Jäger $C$, Petersen $L$ : An outbreak of sheep-associated $Q$ fever in a rural community in Germany. Eur J Epidemiol 1998, 14:193-199.

39. Yanase T, Muramatsu Y, Ueno H, Morita C: Seasonal variations in the presence of antibodies against Coxiella burnetii in dairy cattle in Hokkaido. Japan. Microbiol Immunol 1997, 41:73-75.

40. Hellenbrand W, Breuer T, Petersen L: Changing Epidemiology of Q Fever in Germany, 1947-1999. Emerg Infect Dis 2001, 7:789-796.

41. Loukaides F, Hadjichristodoulou C, Soteriades ES, Kolonia V, loannidou MC, Psaroulaki A, Tselentis Y: Active surveillance of $Q$ fever in human and animal population of Cyprus. BMC Infect Dis 2006, 6:48.

doi:10.1186/1746-6148-7-13

Cite this article as: Cantas et al: $\mathrm{Q}$ fever abortions in ruminants and associated on-farm risk factors in northern Cyprus. BMC Veterinary Research 2011 7:13.

\section{Submit your next manuscript to BioMed Central and take full advantage of:}

- Convenient online submission

- Thorough peer review

- No space constraints or color figure charges

- Immediate publication on acceptance

- Inclusion in PubMed, CAS, Scopus and Google Scholar

- Research which is freely available for redistribution

Submit your manuscript at www.biomedcentral.com/submit 